\title{
Humanistic Science of Nations: Search for the Unifying Idea of the Russian Civil Nation
}

\author{
Alexander Petrovich Bandurin 1 \\ Svetlana Ivanovna Imgrunt ${ }^{2}$ \\ Vladimir Alexandrovich Kirik ${ }^{3}$ \\ Anna Mikhaylovna Shapovalova ${ }^{4}$ \\ Yury Grigorievich Volkov 5
}

\begin{abstract}
${ }^{1}$ Southern Federal University, Rostov-on-Don, Russian Federation 2Southern Federal University, Rostov-on-Don, Russian Federation ${ }^{3}$ Southern Federal University, Rostov-on-Don, Russian Federation ${ }^{4}$ Southern Federal University, Rostov-on-Don, Russian Federation ${ }^{5}$ Southern Federal University, Rostov-on-Don, Russian Federation Correspondence Email: infoippk@sfedu.ru
\end{abstract}

\section{Doi:10.5901/mjss.2015.v6n4s4p254}

\section{Abstract}

This article substantiates an important thought on the significance of humanism ideology in the definition of the national idea in Russian society. The author of the article, basing on the detailed and thorough analysis, concludes that the search of a national idea out of humanistic coordinates is doomed to a failure, since the national idea in Russian society can be the idea of justice, solidarity and optimism. The complexity of the national idea reflection is that meanings and values, inappropriate for national humanistic tradition are often attributed to it. For the author of the article, humanism is a basic prerequisite for the acceptance the integrative effect of humanistic values in the Russians' mass consciousness in the formation of the national idea.

Keywords: nationology (the science about nations), the ideology of humanism, national idea, national identity, inter-ethnic conflicts, consolidation of the society.

\section{Introduction}

The events of the last decade show that the development of a new Russian statehood, integrity strengthening, the unity of the country, social consolidation of Russian society necessitate the formation of a national state ideology.

From the perspective of representatives of de-ideologization theory originating in 60-70-ies of the twentieth century due to the liberal version of the socio-political systems' convergence, any ideology is totalitarian and leads to the restriction of free thought, while a democratic state can only be de-ideological.

However, if you define a positive meaning of ideology, ideology as a system of beliefs, aimed at combination of public and private interests, at developing value-normative consensus in the society, we can talk about the relevance of ideology, as a condition of socio-cultural modernization of Russian society-a creative modernization.

Ideology is a sort of "brain and a ramified system" of the society. With the destruction of the ideological structure, all society sectors begin to act separately and gradually destroy. The ideological structure as the reason of the society determines the development of all its spheres (Volkov, 1995).

\section{Literature Review}

Nowadays, one can watch the ideological discourse actualization. Increasingly, researchers are turning to the question of the national idea search and the analysis of the essence and role of ideology in the society. Thus this phenomenon has been developed in the works of such authors as: V.V. Bursevich (Bursevich, 2010), K. Girtz (Girtz, 1998), S. Zhizhek (Zhizhek, 1999), V. N. Kuznetsov (Kuznetsov, 2008), Y. Matz (Matz, 1992), A.I Yakovlev (Yakovlev, 2001)

The relationship between ideology and political, economic, social, spiritual and other processes is found by such Russian researchers such as Y.G. Volkov (Volkov, 2006), V.V. Zotov (Zotov, Spitsina, 2014), B.G. Kapustin (Kapustin, 
2010), S.G. Kara-murza (Kara-murza, 2002).

In the modern era, there is a redefining of the bases of classical humanism. In the face of global crises, the "new humanism" has been developed in the works of D. Meadows (Meadows, 1994), A. Peccei (Peccei, 1985). The role of ideology in the modern world is seen anew by such researchers as James p. and Steger M. (James, Steger, 2010), Jost, J.T., Ledgerwood A. and Hardin (Jost, Ledgerwood \& Hardin, 2008).

The research works of Y.G. Volkov (Volkov, 2010) and Malitskiy V.S. (Maltskiy, 2004) have a fundamental meaning for our study in identifying the humanist way of the nation unification and finding the national idea based on the ideas of humanism.

\section{Results and Discussion}

Having faced with problems of national interests' realization, with the demand for national identification and, therefore, the definition of the domestic and foreign policy priorities, the Russian state lacks a unifying idea - the idea, which, like as an image of the future, as the highest value of public life, performs a paramount role in overcoming the spiritual crisis. Ideology always speeds up the people's spirit recovery. Rebirth and development of many modern national communities-which had been the societies of economic and social problems by that modernization period — were built on the principles of a new ideology.

When they say that you should first build an innovative economy, to overcome corruption and then ponder think of ideological meanings of our lives, they are lying. It is our belief that for Russia's development, the humanistic ideology is an organized form of public life, a mobilization force acting not on the principle of negative freedom, but of the meaningful assertion of social ideals and objectives.

Currently, the mass consciousness of the Russian society once again has raised questions like "Who are we? ", "Where are we going?" and "What shall we hope for?" It is also noted that the growth of social welfare by itself does not solve the problem of ideological meaning or of the spiritual sphere degradation. Lately there has been a debate about the relevance of the discussion on the Russian national idea - the idea that would unite Russians regardless of social, ethnic, religious and cultural differences.

It is obvious that the introduced idea of tolerance, while being outwardly consistent with the European standards and associated with the practices of tolerance as a way to overcome ethnic and religious conflict, in our view, still accumulates only the experience of the European communities, forced to act by the formula of tolerance in the face of real conflicts, emerging ethnic enclaves and refusals of social and cultural integration and assimilation programs.

Russia, with its unique experience of living and peaceful existence of peoples and faiths should be more critical of the introduction of seemingly ready-made formulas of tolerance.

Tolerance in its minimalist option means not just getting used to "others" or a neutrality to "others", but also the abandonment of a unifying, consolidating goals and ideas, taste to different styles and reformatting of mental and behavioral practices in various life situations. In other words, both a personality, and a society are suggested to develop without an ideal, without what is called the mood of public life.

It is clear that we are not talking about Russian national messiahnism, or about becoming a God-faithful people, a Messiah people (Maslin, 1992). The reason is that Russian society can develop if the formation of the Russian political nation will become a reality. Here we mean the nation that includes the diversity of cultures, beliefs and ethnicities, part of the general process of social construction and maintaining the integrity and identity of the Russian State-nation. Whatever the shortcomings of discussing the issue of the national idea are, first of all, there is always the reminder: a national idea cannot be constructed from above as a result of the society creativity, development of integral positions from a variety of public interests. We can't leave out the following questions: what are the real prerequisites for the formation of national idea in the society; what are the social groups that can demonstrate their subjectivity in relation to the national idea, behavior, and activities of such groups may indicate that the national idea has become an attractor of public opinion.

No less important is whether there are any ideological presuppositions of reformulating the national idea, what ideologies, intentions, traditions we can invoke when supporting the idea of prosperity and putting together the Russian society. Humanistic ideology is often identified with the introduction of abstract universal ideals, with globalization, with opposing the national original to the ideas detached from the realities of public life, from the national spirit and frame of mind.

We are convinced that humanistic tradition of Russian thought is the proof of generations' continuity and it shows that the national idea in the current conditions dates back to the creativity of Russian society as the embodiment of real humanism. We mean that in the public consciousness, although creativity was associated with the sphere of moral values 
(art, literature), opposed to the formal, state-owned in political conflicts, in identifying patterns of relationships between the society and the state, the individual and the State, insufficient justification of the national idea, based on traditional categories of strength and power was found to varying degrees. In other words, social passionarity, social energy remained unclaimed.

It was and is evident that for Russia, the humanistic ideology acquired the internally directed sense, it encouraged to think both about existential problems of humanity, and about who is a personality in Russia, how we can bridge the gap between the low consumer culture and high thoughts, conservatism of state forms and progressiveness of public aspirations.

It is important, in our view, not to fall into another utopia, to overcome anti-ideological syndrome as a syndrome of utopia, the fear to build an inhumane society of totalitarian type. The analysis of the considered circumstances suggests the obvious gap between the reality of life, narrow-minded masses formation and an ideal hero typical of ideological motivation of any projects for the transformation of society and man.

In order to find the reasons, conditions and factors of national idea influence on public life of Russian society, we must proceed from the dynamics of public requests, from what Russians associate with their future and what is seen as the role of the society, the society that is tired of being in the position of bystanders and is aimed at constructive cooperation with the state as the embodiment of the common welfare, as a guarantor of citizens' rights and freedoms as an ideal construct of public life.

We believe that, despite the seeming differences between the humanism ideology and political expediency, the logic of both public life, and Russian statehood formation coincide because the national idea as an ideal of social development combines the efficiency of public administration and creative practices of the society. In favor of this condition, one can mention the fact that, the position of the non-repetition of the worst scenarios of decay and disintegration dominates in Russian society, despite the problems of social stratification and ethnic conflict. Most Russians are aware that without a united state, outside of a single political nation, the assessment of solutions to the problems that concern the Russians-social justice and the rule of law- will be problematic.

What is the correlation between the emerging social practices, the creativity transition from individual in collective heritage, the emerging outline of humanistic ideology and national idea? K. N. Leontiev wrote that European and Christian humanity are undoubtedly opposed, even difficult to coexist, one shouldn't be surprised or terrified with such an idea, though it is sad (Maslin, 1992). Of course, we cannot identify the current ideological situation with the situation in the second half of the 19th century, but there is a recurrence of the problems faced by the new generations. This continuity is that public life is dead and boring, if not encouraged by the high idea, if refraining from literature-centrism and utopianism leads to pointless consumer practices becoming a priority.

Many critical reviews followed this idea. One can set semantic boundaries in the national idea definition. Firstly, the national idea cannot be utopian, repeating the negative experience of building a society of absolute equality and justice. Secondly, the national idea cannot be an idea of consumerism, the idea, aimed solely at growth of material well-being and following the average European variant.

Judging by the European Union experience, difficulties do not begin in the context of the financial and economic crisis, conflicts over a specific share of the national community in the European "pie"; complexities are associated with the European idea deficiency, with the fact that the formation of the European consciousness cannot be given to supranational bureaucratic structures, that Europeism cannot be based on speculation of protection from Russian, Islamic or other fictional or real threats.

We believe that a focus on the national idea is determined by finding the spiritual unifying elements in the public consciousness. Despite the seeming social atomization, individualizing strategies dominance, the mass consciousness of the Russian society discovers consolidating intentions. This is reflected in the fact that, according to M.K. Gorshkov, the attitude to public life as to a stranger's life is unproductive. Characteristically, for the successful implementation of national modernization project it is important to ensure social justice (31\%), as well as the principle of everybody's equality before the law (41\%) (Gorshkov, 2011). These positions of Russians prove, firstly, the anti-utopian aspirations, and secondly, that the Russians' interests are aimed at being a part of social life, as neither social justice nor the rule of law can be achieved in a state of social disintegration.

Increase of pluralism of individuals and social groups' interests is not only expressed in new social regulators, but also in consolidating creative practices. Without minimizing the importance of economics and politics, we can say that the humanistic ideology, "multiplied" by social creativity, creates a new value-normative society structure. The Russians developed a tolerant attitude to individualism (61\%) (Gorshkov, 2011), and therefore one cannot be mechanically transfer the formulae of collegiality. We can say that it's the process of life strategies' individualization that enhances motivation for social cohesion, because while under individualistic delusions, a need for a new collectivism is formed. 
What might it be? What could become a center of emerging humanistic practices' combination in the society? Believing that a refusal from the "dry" and self-confident utilitarianism is justified and, in this regard, the humanist ideology leads to a belief in the human value, which humanism reveals self-confidence of individual motives. The positive trend is that the process of life attitudes' individualization developed a feature to apply to the world with its own efforts.

In other words, an individual's reliance on his own strength cultivates the personality's responsibility and independence, if not addressed to a general abstract humanity, but diverted to harmonize interests, to determine the format of joint activities and what the Russian philosopher N. E. Kareev describes as "tactile and understandable love" (Maslin, 1992).

Considering the Russian society as the society of unrealized potentials (Volkov, 2011), we mean that the creative potential of Russian society, tradition of shared environment, public life spirituality prepared a fertile ground for a community development. Still a gap between social independent attempts and state building remains a barrier to social creativity, while the "gap" between them was filled with inhuman pseudo-ideological constructs.

In the relationship between the individual and the society, the individual and the State a zone of mutual alienation and distrust or, conversely, paternalism extended. In both cases the social creativity was limited because hopes were associated either with an omnipotent State apparatus, or with individual and group survival strategy.

In the circumstances where the Russian society is forced to choose the path of sustainable social development, to safeguard against catastrophic scenarios, against the cumulative effect of internal and external (global) challenges, it becomes certain to understand the ideology of building a creative society-the society of a creative constellation.

Intuition of overall unity, which is present in the Orthodox tradition, gives the possibility of harmonizing grace and liberty (Maslin, 1992). This is a valuable feature of the synthesis of individual freedom and collective welfare.

Specifying the general considerations expressed here, it may be noted that the persistent struggle against rationalism, empirism, attributed to the Russian national tradition, is hypostased, not related to the actual rises of science, arts, literature in previous historical periods.

In contrast to theism (Maslin, 1992), which is always specifically and historically limited, the humanistic ideological tradition is cosmic, addressed to various population groups and prevents the society's self-enslaving (Volkov, 1995). The effect of mutual suppression with civilized order through the struggle of interests or through one-dimensional transformation of society and person is expressed in depriving the human relations of their humanity, in the national idea being embedded with the meaning of domination on the political, cultural, and spiritual level.

In the Russian humanistic tradition, a society based on authentic human values, creatively understands its location and role in world-comprehension, cognition and spiritual harmony realization at the individual and collective levels. The national idea consideration involves figuring out its social quality as a creatively acting one. The role of humanism ideology is important because creativity cannot be inhumane by definition, it can be only humanistic. Otherwise, this is destruction, human nature exclusion.

Saying that humanism can be bound to utopian reasons, you can easily make a mistake in choosing the critics addressee. A modern ideological type of Russian society brings together representatives of different projects on social life improvement. Yet at the core, there is a position of adoption of social creativity that does not require any proof of its eternal metaphysical qualities (Geller, Nike, 2003). The Russian philosopher S. L. Frank wrote that if we look deeply enough, and take a broad view on common European space, then the Russian revolution will become a model of reducing the spiritual life intensity, decrease in spiritual quest. This, with the revolutionary consciousness' appearance, is connected, despite the outer look, not only with the disinterested belief in a gust of any objective truth, but also with a whirlwind of blemish, outrages and with sorrows (Maslin, 1992).

We can say that revolutionarism in Russian society is reproduced because of the lack of social creativity, the presence of distorting, rebel-destructive features in the masses' sentiments. This is possible because in a society where humanistic meanings are being lost, social hatred social ills start to dominate, while the attitude to the national idea gets very skeptical. The very possibility of society reorganization according to the co-creating ideological principles is denied.

The national idea is not a project for the modern society, but a vital necessity. This is proven with the Russians' demand for the better, equitable State, the desire to be socially useful and work for one's own and others' benefit. Behind these routine positions one may find a trend of return to consolidation. It is clear that, in spite of the injustice of social inequalities and the demand for social justice, public consciousness is not ready and does not want another violent justice restoration. Humility, reconciliation with the circumstances, relying on the resource of patience, however, beget spirit deviation obscurantism, different ideological cults, which possess passionary but socially disoriented minority.

To get the national idea embodied, to make it an encouraging and material strength of the masses' consciousness, bridging the gap between social creativity and humanistic ideology seems to be indisputable. The problem is only that the humanistic principles, which are manifested in the above mentioned intentions of mass consciousness, are prone to 
situations, diffusion elsewhere outside the binding ideological context, beyond understanding that humanism is not contrary to the national cultural tradition.

The national idea-the idea of a more reasonable and fair society - is fixed by mass consciousness, considering the fact that public sentiment is dominated by the idea of social justice, equal rights for everybody (from $32 \%$ to $49 \%$, depending on the ideological orientations) (Gorshkov, 2012). The national idea is determined in relation to the social creativity as a real way of achieving equality of opportunities and freedom of self-expression. A creative society includes the ideals of social justice and democracy, stability and development. This assertion is not general, assuming that the national idea achievement is conceived as integration, synthesis of constructive meanings, expressed in attitudes to the authorities and the state, to the west and to the east, to the national issues (Gorshkov, 2012).

Such an attitude is not contemplative, because a significant number of Russians (39\%) mostly appreciate activity and initiative in people (Gorshkov, 2011). This fact shows that the mere inclusion of the society in the national idea discussion is an opportunity to include a social initiative. It also shows that social order is to articulate the national idea in social and creative practices - the practices aimed at both consolidating of the national tradition, and at the development of social participation forms, joint actions, in which the Russians realize themselves as groups of equal opportunities. This is where the humanistic sense, humanistic orientation, return to the value of human life, its dignity and priority in solving social problems are expressed.

It's worth pointing out that for a creative society, including the Trinity of justice, creativity and legality, the criterion of social development is the national idea as the ideal model of interaction between the society, the individual and the State (Volkov, 2011). In our view, the weakness of previous debates on national idea could be called the separation of spirituality and sociality, cultural ideals and public demands. S. L. Frank, who believed that the Russian Revolution was just the result of sociality oblivion (Maslin, 1992), noted this fact.

\section{Conclusion}

One can talk about uniting the national ideas outside the social context, as well as about opportunism, pragmatism of social demands beyond the comprehension of social values and meanings. Social creativity moves to the national idea, because it assists understanding its certainty in a creative space. The social creativity as spiritual meanings' turning onto social norms and rules, gives the national idea its stimulating, acting meaning. The reason for the gap between the Russians' evaluating judgements, the pursuit of the social justice ideal can be seen in indefinite character of the contemplative, literature-centered attitude to the ideal as to what is incomprehensible, as to what you can declare, but you cannot make a scheme of activity.

In creativity, where humanistic orientation, awareness of the personal value has a consolidating sense, the national idea is perceived as the idea of creatively thinking, like-minded people. The State of Russian society presumes that the attitude to the national idea itself can be characterized as learning from the past, a sense of spiritual tradition continuity with construction, the inclusion of creativity and the process of creativity individualization, the adoption of the formula of a just society as the society of creativity, aimed at self-realization and personal development.

\section{Acknowledgements}

This research was financially supported by the internal grant from the Southern Federal University No. 213.01-07$2014 / 15 П Ч В Г$ "Threats to the national security in the face of geopolitical competition and models of aggressive and hostile behavior of young people".

\section{References}

Bursevich, V.V. (2010) Criticheskiy I neytral'niy podkhody k issledovaniyu ideologii: sravnitel'niy analiz // Vestnik PSU. №1. Humanities issue. [in Russian]

Geller, L. \& Nikke, M. (2003) Utopiya v Rossiyi. SpB. [in Russian]

Girts, K. (1998) Ideologiya kak kul'turnaya sistema // Novoye literaturnoye obozreniye. № 29. [in Russian]

Gorshkov, M.K. (2011) Rossiyskoye obtschestvo kak ono est'. M. [in Russian]

Gorshkov, M.K. (edited) (2012) O chem mechtayut Rossiyane? M. [in Russian]

James, P.; Steger, M. (2010). Globalization and Culture, Vol. 4: Ideologies of Globalism. London: Sage Publications.

Jost, J.T., Ledgerwood, A., \& Hardin, C.D. (2008). Shared reality, system justification, and the relational basis of ideological beliefs. Social and Personality Psychology Compass

Kuznetsov V.N. (2001) Sotsiologiya ideologii. M., 2008; Yakovlev A.I. Gosudarstvennaya ideologiya. Kaluga: Oblizdat. [in Russian] 
Malitskiy V.S. (2004) Ideologiya i gumanizm. Moscow [in Russian]

Maslin M.A. (comp.) (1992) Russkaya ideya. M. [in Russian]

Mats, U. (1992) Ideologiya kak determinant politiki v epokhu moderna // Polis. №1-2. [in Russian]

Meadows, D.Kh. (1994) Za predelami rosta / D.Kh. Meadows, D.L. Meadows, Y.Runders / Translation from Eng.into Russian by G.Y. Yagodin. M.: Progress Pangeya. [in Russian]

Peccei, A. (1985) Chelovecheskiye kachestva / A. Peccei: Translated from Eng. M.: Progress. [in Russian]

Volkov Y.G. (1995) Lichnost' i gumanism. Chelyabinsk. [in Russian]

Volkov Y.G. (2011) Kreativnost': istoricheskiy proryv Rossiyi. M. [in Russian]

Volkov Y.G. (2000) Manifest gumanizma. (Ideologiya I gumanisticheskoye budutscheye Rossiyi) M.: «Sots.- gumanit. znaniya». [in Russian]

Zhizhek, S. Vozvishenniy ob'ekt ideologiyi. M.: Khudozhestvenniy zhurnal, 1999. [in Russian] 